\title{
PEMILIHAN UMUM DALAM SISTEM DEMOKRASI PRESPEKTIF SILA KE- 4 PANCASILA
}

\author{
Yusuf Eko Nahuddin \\ Fakultas Hukum Universitas Merdeka Malang \\ Jl. Terusan Dieng No. 62-64; Malang; 65146; Indonesia; (0341) 580161 \\ yusuf.eko@unmer.ac.id
}

\begin{abstract}
Elections are a manifestation of democracy reflecting the fourth principle of Pancasila. Elections that prioritize the dialogical approach of vision and mission as a solution to the nation's problems undertaken by election participants who truly reflect the soul-bearing souls of Pancasila. Selected individuals who meet the criteria of election are credibility, integrity and acceptability as well as popolarity due to achievement, dedication and loyalty to the nation and country that are worthy to lead this country. The development of many election participants who can not reflect the value of democracy according to the 4th principle of Pancasila. The method used is normative with the approach of norms and existing theories reviewed to solve the issues raised. The use of political parties plays a major role in creating elections that reflect the value of Pancasila. Pancasila is the foundation of the nation's philosophy is the root of life of the nation of Indonesia in carrying out its life must always be held firm. General election merupkan form of democracy that berprespektif Pancasila to seek leaders of noble personality who practice Pancasila so as to bring progress and prosperity of the nation and state of Indonesia.
\end{abstract}

Keywords: Pancasila Come 4th Century, Democracy, Elections.

\begin{abstract}
Abstrak
Pemilihan umum merupakan wujud terlaksananya demokrasi yang mencerminkan sila ke-4 Pancasila. Pemilihan umum yang mengedepankan pendekatan dialogis visi dan misi sebagai solusi persoalan bangsa yang dilakukan oleh peserta pemilihan umum yang benar-benar mencerminkan insan-insan yang berjiwa Pancasila. Insan-insan pilihan yang memenuhi kriteria keterpilihan yakni kredibelitas, integritas serta akseptabilitas dan juga popolaritas karena prestasi, dedikasi serta loyalitas kepada bangsa dan negara yang layak mempimpin negara ini. Perkembangannya banyak peserta pemilihan yang tidak bisa mencerminkan nilai demokrasi sesuai sila ke-4 Pancasila. Metode yang digunakan adalah normatif dengan pendekatan norma dan teori yang ada dikaji untuk memecahkan masalah yang diangkat. Pemanfaatan partai politik berperan besar dalam menciptakan pemilihan umum yang mencerminkan nilai Pancasila. Pancasila merupakan dasar falsafah bangsa merupakan akar kehidupan bangsa Indonesia dalam menjalankan kehidapannya yang senantiasa harus dipegang teguh. Pemilihan umum merupkan wujud demokrasi yang berprespektif Pancasila untuk mencari pemimpin negara yang berkepribadian luhur yang mengamalkan Pancasila sehingga bisa membawa kemajuan dan kesejahteraan bangsa dan negara Indonesia.
\end{abstract}

Kata Kunci: Pancasila Sila ke-4, Demokrasi, Pemilihan Umum. 


\section{Pemilihan Umum dalam Sistem Demokrasi Prespektif Sila Ke- 4 Pancasila}

Yusuf Eko Nahuddin

\section{Pendahuluan}

Pancasila sebagai ideologi bangsa adalah sudah final, namun implimentasi sila-sila Pancasila sebagai landasan bernegara. Praktiknya disadarai atau tidak selalu menarik untuk diperbincangkan serta tidak habis-habisnya untuk dikupas dan dijadikan sebagai landasan berkontemplasi sebagai dasar pijakan untuk membawa bahtera negara menuju tercapainya mimpi-mimpi kehidupan yang sejahtera adil, makmur, aman dan sentosa. Perkambangan dewasa ini keberadaan Pancasila dipermasalahkan serta diragukan terkait keberadaan Pancasila sebagai ideologi bangsa dikambing hitamkan, karena dianggap menyebabkan kondisi bangsa yang tidak mampu progresif dalam menghadapi setiap tantangan globalisasi. Serta dianggap sebagai permasalahan karena Pancasila sebagai ideologi tidak kunjung mampu memberikan sebuah jaminan kesejahteraan.

Perkembangan mendeskreditkan Pancasila sebagai bentuk rasa iri serta ketidakpuasan atas kondisi negera yang masih jauh dari apa itu kesejahteraan. Negara Indonesia dibandingkan dengan negara-negara yang berideologi liberalis atau sosialis yang justru mampu lebih progresif dalam setiap menghadapi kondisi perubahan dan mampu eksis dalam kancah pergaulan antar negara serta lebih kelihatan sejahtera dan maju. Hal ini yang kemudian sering kali Pancasila dikambing hitamkan sebagai penyebab akut yang menjadikan negara ini mengalami keterpurukan. Sehingga komentar serta peryataan yang ingin mengembalikan kemurnian Pancasila menjadi sebuah wacana yang cukup gencar dan masif khusunya dalam kancah dunia Politik ketatanegaraan. Namun hal tersebut merupakan hanya sebatas dilapisan luarnya saja yang kemudian mengeneralkan bahwa Pancasila tidak lagi sakti dan seterusnya.

Mengetahui manfaat Pancasila hendaknya mengupas lebih kedalam lagi, dengan pertanyaan yang amat mendasar yakni apakah nilai-nilai Pancasila sebagai dasar bernegara sudah benar-benar terimplementasi secara benar dan konsisten. Selanjutnya bagaimana bila tidak konsisten apakah Pancasila dalam hal ini sila-sila dari Pancasila itu kemudian berani kita revisi dan atau sebaliknya kondisi baru hendaknya disesuaikan dengan logika nilai-nilai yang terkandung dalam sila-sila Pancasila. Melihat peran serta Pancasila dalam kehidupan hendaknya terlepas dari dialektika yang kontruktif berkaitan dengan persoalan-persoalan saat ini prilaku ketatanegaraan yang berhadapan dengan Pancasila, agar hal tersebut tidak terjadi opini yang tendensius, emosional yang terkesan hanya mengkambing hitamkan Pancasila.

Pancasila sebagai falsafah bangsa serta ideologi bangsa yang kedudukanya sederajat dengan Negara Kesatuan Republik Indonesia (NKRI) itu harga mati maka Pancasila itu harga diri bangsa. Pancasila itu merupakan harga diri bangsa maka tidaklah mudah untuk diperjual belikan dengan kepentingan apapun juga dan bila ada yang memperjual belikan atau mengadaikan Pancasila demi kepentingan praktis maka itu adalah bentuk penghianatan pada bangsa dan negara dan tiada imbalan yang pantas atas penghianat hanyalah hukuman. Oleh karena itu, Pancasila itu tak terhingga harganya dan nilainya.

Pancasila merupakan nilai-nilai keluhuran bangsa Indonesia yang bersifat universal dan selalu hidup dalam setiap hembusan nafas bagi siapa saja kelompok manapun dan adat maupun istiadat bangsa Indonesia yang menjadi nilai-nilai persatuan dan kesatuan yang seharusnya terimplementasi secara konsisten. Oleh karena itu, pencerminan nilai-nilai Pancasila bagi kehidupan berbangsa dan bernegara penting untuk diterapkan dalam kehidupan sehari-hari, salah satunya demokrasi.

Demokrasi yang merupakan pencerminan Pancasila dapat dilihat berkaitan dengan pemilihan umum yang menjadi pilihan cara saat ini yang dilakukan. Hal ini berangkat dari beberapa negara yang menganggap negaranya demokratis untuk menjembatani terpilihnya wakil-wakil rakyat yang 
mencerminkan sebuah gambaran dari rakyat, oleh rakyat dan untuk rakyat (demokrasi). Tentunya penglihantan yang dipakai adalah dengan kaca mata Pancasila tepatnya dalam implimentasi nilainilai Pancasila sila ke- 4 yang berbunyi bahwa "Kerakyatan yang dipimpin oleh hikmah kebijaksanaan dalam permusawaratan perwakilan".

Demokrasi pemilihan umum berdasarkan Pancasila dewasa ini amat perlu dikaji kembali karena patut disadari betul bahwa demokrasi adalah sebagai salah satu isu yang muncul setelah tumbangya rezim orde baru. Sejak kemunduran rezim orde baru isu bahwa selama rezim orde baru dianggap tidak demokratis baik dalam pemilihan maupun dalam setiap penggankatan pejabatpejabat publik serta yang tidak kalah pentingnya adalah dalam setiap pengambilan kebijakan yang dilakukan oleh pemerintah dianggap tidak demokratis. Sehingga kondisi demikianlah yang menjadi semangat orde reformasi untuk menggumandangkan demokrasi sebagai landasan pemerintahan negara ini, sehingga penerapan demokrasi dalam sistem bernegara tidak bisa terbendung lagi.

Namun dalam implimentasinya disadari atau tidak demokrasi yang diterapkan dalam perjalanannya masih jauh dari pada apa yang menjadi substansi demokrasi itu sendiri. Hal ini tampak jelas dan nyata dalam sistem pemilihan umum yang menjadi reperesentasi dari demokrasi banyak terjadi permainan-permainan oknum yang menciderai kemurnian dan kesucian demokrasi itu. Hal tersebut terjadi karena banyaknya potensi tindakan-tindakan ilegal demi sebuah kemenangan sebut saja diantaranya Adanya manipulasi pemilih (manipulasi demografi, penghilangan hak pilih, memecah dukungan oposisi); Intimidasi; Jual beli suara; Penyesatan informasi; Manipulasi kertas suara; Coblos ganda; Manipulasi dalam rekapitulasi; Penggunaan pemilih semu; Merusak kertas suara; Pebajakan sistem teknologi informasi dalam pemungutan suara; Pembajakan hak pilih. Contoh kasus nyata terjadi adalah manipulasi hasil rekapi- tulasi suara yang merupakan penghancuran terhadap nilai demokrasi itu sendiri (Ervianto, 2017).

Ditambah lagi menurut Mulyadi, Staf Ahli Bawaslu ditemukan fakta bahwa potensi permasalahan dalam penyelengaraan pemilu maupun pilkada yang substansi acaranya adalah memilih diantaranya persoalan politik uang, kampanye hitam, intimidasi, penggunaan fasilitas negara, pelibatan anak-anak saat kampanye terbuka, mobilisasi PNS, penggunaan sarana pendidikan dan ibadah untuk kampanye, serta kampanye diluar jadwal (Ervianto, 2017). Hal-hal tersebut merupakan realita kondisi nyata. Kondisi pemilihan umum secara keseluruhan tidak mencerminkan nilai demokrasi dalam pemilihan umum hingga pemilihan kepala daerah yang tentunya menjadi bagian mata rantai yang menyumbang kualitas figur pemimpin dan kualitas kinerja yang tidak baik. Sebab tidak menutup kemungkinan bila penyelewengan tindakan pada saat pemilihan umum apalagi berkaitan dengan tindakan money politik maka tentu akan berupaya mencari keuntungan pada saat memimpin pemerintahan untuk menutupi pengeluaran. Sehingga hal ini akan menjadi penyebab banyaknya penyalahgunaan kekuasaan oleh oknum pimpinan baik tingkat pusat, provinsi, hingga tingkat daerah kabupaten maupun kota.

Keadaan inilah yang kemudian menjadi suatu alasan untuk kembali merenungkan lagi serta mengkaji secara dialogis yang konstruktif berkaitan dengan pemilihan umum. Reorientasi kembali pandangan Pancasila yang menjadi satu-satunya pilihan cara untuk mengimplementasikan demokrasi langsung hingga saat ini. Sehingga atas kondisi-kondisi tersebut diatas dapat bertujuan untuk mengaktualisasi lagi konsep pemilihan umum yang mencerminkan demokrasi. Hal ini berangkat dari permasalahan yang berkaitan dengan bagaimana konsep pemilihan umum dalam sistem demokrasi prespektif Pancasila sila ke -4 yang merupakan perwujudan dari suatu cerminan nilai-nilai luhur 


\section{Pemilihan Umum dalam Sistem Demokrasi Prespektif Sila Ke- 4 Pancasila}

Yusuf Eko Nahuddin

yang hidup dan berkembang yang tumbuh dan melekat menjadi jatidiri bangsa yang mampu mewujudkan demokrasi substantif hingga tercapi negara yang berdaulat adil dan makmur.

\section{Pembahasan}

\section{A. Pemilihan Umum Sebagai Sarana Demokrasi.}

Bahwa satu-satunya cara untuk mengikut sertakan rakyat dalam menentukan calon-calon pemimpin dan wakil-wakilnya di parlemen adalah dengan cara menyelengarakan pemilihan umum. Cara ini dianggap oleh hampir semua negara yang menganut sistem demokrasi sebagai cara yang paling efektif dan yang paling memungkinkan untuk dilaksanakan karena bisa mengikut sertakan semua rakyatnya secara langsung dalam pesta demokrasi setiap periode pergantian pemimpin hal ini sebagai cerminan terlaksananya sistem demokrasi terlebih juga di Indonesia yang juga menyatakan dirinya sebagai negara yang demokratis.

Apa yang tersampaikan diatas sejalan dengan alasan disahkanya Undang-Undang Republik Indonesia No. 7 tahun 2017 tentang Pemilihan Umum (UU Pemilu) sebagai dasar dilaksanakanya pemilihan umum. UU Pemilu sebagai sarana perwujudan kedaulatan rakyat untuk menghasilkan wakil rakyat sebagai pemimpin bangsa dan negara. Wakil rakyat tersebut mulai dari Dewan Perwakilan Rakyat, Dewan Perwakilan Daerah dan Dewan Perwakilan Rakyat Daerah yang aspiratif, berkualitas serta bertanggungjawab berdasarkan Pancasila dan Undang-Undang Dasar Republik Indonesia Tahun 1945 (UUD 1945). Oleh karena itu, UU Pemilu menjamin tersalurkanya suara rakyat secara langsung, umum, bebas dan rahasia serta jujur dan adil.

Berdasarkan ketentuan Pasal 1 angka (1) UU Pemilu, pemilihan umum (pemilu) merupakan sarana pelaksanaan kedaulatan rakyat yang dilaksanakan secara langsung, umum, bebas, rahasia, jujur, dan adil dalam Negara Kesatuan Republik Indonesia berdasarkan Pancasila dan UUD 1945. Pemilu yang diselengarakan oleh Komisi Pemilihan Umum, selanjutnya disebut KPU sebagai lembaga penyelengara pemilu yang bersifat nasional, tetap dan mandiri yang bertugas melaksanakan pemilu secara berkala setiap 5 (lima) tahun sekali.

Pemilu adalah sarana demokrasi yang dari padanya dapat ditentukan siapa yang berhak menjalankan tugasnya di lembaga politik negara, legislatif dan/atau eksekutif. Melalui pemilu rakyat memilih figur yang dipercaya yang akan mengisi jabatan legislatif dan/atau jabatan eksekutif. Pelaksanaan pemilu diberikan kepada rakyat yang telah memenuhi persyaratan untuk memilih, secara bebas dan rahasia, menjatuhkan pilihanya pada figur yang dinilai sesuai dengan aspirasinya. Tentunya tidaklah mungkin seluruh aspirasi dapat ditampung, dari sekian banyak pilihan aspirasi maka yang mendapatkan suara terbanyak pemilih dinyatakan sebagai pemenang karena mewakili kehendak rakyat terbanyak atau mayoritas (Ranadireksa, 2007).

Bahwa salah satu aspek yang menjadi substansi dari memaknai demokrasi adalah mengakui dan menghormati suara mayoritas. Sedangkan arti dari mayoritas itu sendiri dalam suatu demokrasi bukanlah sesuatu yang lahir dari asumsi atau sekedar klaim kuantitas yang bersifat konstanta. Klaim mayoritas tanpa pemilu yang hanya berdasarkan atas nama suku, agama, ras, atau golongan (petani, buruh dan lain-lain) bukanlah suatu cerminan dari demokrasi, melainkan suatu bentuk tirani. Selanjutnya disampaikan juga bahwa Pemilu adalah merupakan arena uji publik atas visi dan program yang ditawarkan oleh siapapun baik partai atau individu yang merupakan wujud implementasi kedaulatan rakyat.

Dengan sistem pemilihan umum maka harus diakui bahwa demokrasi adalah satu-satunya sistem yang membuka ruang bagi lahirnya dan tumbuhnya aneka ragam visi maupun ideologi. Pekem- 
bangan tersebut yang kesemuanya memiliki kemungkinan yang sama untuk berkembang dengan bebas dengan catatan sejauh ideologi itu bukan merupakan ideologi yang dilarang oleh negara. Bahkan ideologi yang bertentangan dengan nilainilai ideologi yang dianut oleh negara yang bertujuan untuk membungkam atau melenyapkan paham atau ideologi yang ada. Dimana tujuan akhirnya adalah demi terciptanya suatu kesejahteraan negara sebagaimana yang dicita-citakan.

Sedangkan demokrasi itu sendiri adalah terbukanya ruang yang kondusif dan efektif untuk tercapainya prinsip dari rakyat, oleh rakyat dan untuk rakyat. Hal tersebut yang mengandung arti bahwa pemimpin lembaga negara murni berasal dari rakyat melalui pemilihan umum sebagai wujud atas perlindungan dan penegakan hak bagi setiap warga negara. Hak ini berupa hak untuk memilih maupun dipilih sebagai pejabat negara yang mewakili kepentingan rakyat diatas kepentingan pribadi maupun golongan. Oleh karena itu, cara meraih hak warga negara adalah melalui sistem pemilihan umum yang diselengarakan oleh lembaga yang mandiri dan independen.

Kondisi diatas sejalan dengan nilai-nilai demokrasi yang disampikan oleh Henry B. Mayo dalam bukunya yang berjudul introduction to democratic theory yang memberikan difinisi demokrasi sebagai sistem politik, dikatakan bahwa sistem politik yang demokratis adalah suatu sistem dimana kebijaksanaan umum ditentukan atas dasar mayoritas oleh wakil-wakil yang diawasi secara efektif oleh rakyat dalam pemilihan-pemilihan secara berkala yang didasarkan atas prinsip kesamaan politik dan diselengarakan dalam suasana terjaminya kebebasan politik (Huda, 2014).

\section{B. Nilai-Nilai Luhur Sila Kerakyatan yang Dipimpin oleh Hikmat Kebijaksanaan Dalam Permusyawaratan Perwakilan.}

Pancasila sila ke-4 yang berbunyi kerakyatan yang dipimpin oleh hikmat kebijaksanaan dalam permusyawaratan perwakilan merupakan penjelmaan dalam dasar politik negara. Berkedaulatan rakyat yang menjadi landasan mutlak dari pada sifat demokrasi negara Indonesia yang tidak dapat dirubah ataupun ditiadakan. Sifat dari persatuan dan kesatuan dari Pancasila, sila ke-4 mengandung pula sila-sila lainnya sehingga kerakyatan yang dimaksud adalah kerakyatan yang berKetuhanan yang Maha Esa, yang berkemanusiaan yang adil dan beradap, yang mencerminkan persatuan bangsa Indonesia dan yang berkeadilan sosial bagi seluruh rakyat Indonesia.

Lambang binatang banteng atau lembu liar adalah merupakan binatang sosial yang sama halnya dengan manusia yang berjiwa sosial. Dimana dalam penentuan keputusan diambil dengan bersama-sama atau bernusyawarah, gotong-royong dan kekeluargaan dimana nilai-nilai ini adalah merupakan nilai-nilai yang khas dan hidup dalam kehidupan bangsa Indonesia yang terjelma dalam nilai nilai dasar negara.

Menurut Syahri adapun makna dari sila ke4 Pancasila adalah:

a. Nilai luhur yang mengutamakan kepentingan negara dan masyarakat diatas kepentingan pribadi maupun golongan;

b. Nilai luhur yang tidak memaksakan kehendak kepada orang lain;

c. Nila luhur yang mengutamakan budaya bermusyawarah dalam mengambil keputusan bersama;

d. Nilai luhur bermusyawarah sampai dengan tercapainya kata mufakat yang diliputi dengan semangat kekeluargaan.

Selanjutnya adapun arti dan makna dari setiap frasa dari sila keempat adalah:

1. Hakekat sila ke-4 adalah demokrasi, dimana yang dimaksud demokrasi disini adalah demokrasi dalam arti umum yaitu pemerintahan dari, oleh dan untuk rakyat dimana secara sederhana, demokrasi yang melibatkan segenap 


\section{Pemilihan Umum dalam Sistem Demokrasi Prespektif Sila Ke- 4 Pancasila}

Yusuf Eko Nahuddin

bangsa dalam pemerintahan baik yang tergabung dalam pemerintahan maupun yang diluar pemerintahan karena peran rakyat yang diutamakan.

2. Pemusyawaratan artinya mengusahakan putusan secara bulat, dan sesudah itu diadakan tindakan bersama. Disini terjadi simpul yang penting yaitu mengusahakan keputusan secara bulat. Bulat yang dimaksud adalah hasil yang mufakat, artinya keputusan itu diambil dengan kesepakatan bersama, dengan demikian berarti bahwa penentu demokrasi yang berdasarkan Pancasila adalah kebulatan mufakat sebagai hasil kebikjasanaan. Oleh karena itu jika ingin memperoleh hasil yang sebaik-baiknya didalam kehidupan bermasyarakat, maka hasil kebikjasanaan itu harus merupakan suatu nilai yang ditempatkan lebih dahulu.

3. Dalam melaksanakan keputusan diperlukan kejujuran bersama, dalam hal ini perlu diingat bahwa keputusan bersama dilakukan secara bulat sehingga membawa konsekuensi adanya kejujuran bersama. Perbedaan secara umum demokrasi di barat dan di Indonesia yaitu terletak pada permusyawaratan, Permusyawaratan yang dimaksud adalah permusyawaratan yang menghasilkan keputusan-keputusan yang diambil berdasarkan suara bulat.

Nilai-nilai diatas menjadi nilai yang dianut serta menjadi pandangan bangsa Indonesia. Bagi bangsa Indonesia yang berpegang teguh pada nilai-nilai Pancasila apabila pengambilan keputusan secara bulat itu tidak bisa tercapai dengan mudah, baru diadakan pemungutan suara sebagai cara terakhir. Kebijaksanaan ini merupakan suatu prinsip bahwa yang diputuskan itu memang bermanfaat bagi kepentingan rakyat banyak. Jika demokrasi diartikan sebagai kekuatan, maka dari pengamatan sejarah bahwa kekuatan itu memang berada pada tangan rakyat atau masyarakat.
Secara sederhana, pembahasan sila ke 4 adalah demokrasi. Demokrasi yang mana dipimpin oleh hikmat kebijaksanaan. Pemimpin yang hikmat adalah pemimpin yang berakal sehat, rasional, cerdas, terampil, dan seterusnya pada hal-hal yang bersifat fisik/ jasmaniah; sementara kebijaksanaan adalah pemimpin yang berhatinurani, arif, bijaksana, jujur, adil, dan seterusnya pada hal-hal yang bersifat psikis/ rohaniah.

Pemimpin yang hikmat-kebijaksanaan itu lebih mengarah pada pemimpin yang profesional (hikmat) dan juga dewasa (bijaksana). Negara demokratis yang dipimpin oleh orang yang dewasa profesional dilakukan melalui tatanan dan tuntunan permusyawaratan/ perwakilan. Tegasnya, sila keempat menunjuk pada NKRI sebagai Negara demokrasi-perwakilan yang dipimpin oleh orang profesional-dewasa melalui sistem musyawarah yang berasaskan kekeluargaan dengan kesadaran bertanggung jawab terhadap Tuhan Yang Maha Esa menurut keyakinan beragama masing-masing, dan menghormati nilai-nilai kemanusiaan ke atas harkat dan martabat manusia, serta memperhatikan penguatan dan pelestarian kesatuan nasional menuju keadilan sosial.

Secara filosofis nilai yang terkandung di dalamnya adalah bahwa hakikat negara sebagai penjelmaan sifat kodrat manusia sebagai makhluk individu dan makhluk sosial. Hakikat rakyat adalah merupakan sekelompok manusia sebagai makhluk Tuhan yang Maha Esa yang bersatu yang bertujuan muwujudkan harkat dan martabat manusia dalam suatu wilayah negara (Muslimin, 2016). Rakyat adalah merupakan subjek pendukung pokok negara. Negara adalah dari, oleh dan untuk rakyat, oleh karena itu rakyat adalah merupakan asal mula kekuasaan negara.

Selanjutnya dalam sila kerakyatan terkandung nilai demokrasi yang secara mutlak harus dilaksanakan dalam kehidupan bernegara. adapun nilai-nilai demokrasi yang terkandung dalam sila keempat adalah: 
a. Adanya kebebasan yang harus disertai dengan tanggung jawab baik terhadap masyarakat bangsa maupun secara moral terhadap Tuhan yang Maha Esa;

b. Menjunjung tinggi harkat dan martabat manusia;

c. Menjamin dan memperkokoh persatuan dan kesatuan dalam hidup bersama;

d. Mengakui atas perbedaan individu, kelompok, ras, suku, agama, karena perbedaan adalah merupakan suatu bawaan kodrat manusia;

e. Mengakui adanya persamaan hak yang melekat pada setiap individu, kelompok, ras, suku, maupun agama;

f. Mengarahkan perbedaan dalam suatu kerja sama kemanusiaan yang beradab;

g. Menjunjung tinggi atas musyawarah, sebagai moral kemanusiaan yang beradab;

h. Mewujudkan dan mendasarkan suatu keadilan dalam kehidupan sosial agar tercapainya tujuan bersama.

i. Sebagai warga negara dan warga masyarakat, setiap manusia Indonesia mempunyai kedudukan hak dan kewajiban yang sama;

j. Tidak boleh memaksakan kehendak kepada orang lain;

k. Mengutamakan musyawarah dalam mengambil keputusan untuk kepentingan bersama;

1. Musyawarah untuk mencapai mufakat diliputi oleh semangat kekeluargaan;

m. Menghormati dan menjunjung tinggi setiap keputusan yang dicapai sebagai hasil musyawarah;

n. Dengan itikad baik dan rasa tanggung jawab menerima dan melaksanakan hasil keputusan musyawarah;

o. Di dalam musyawarah diutamakan kepentingan bersama di atas kepentingan pribadi dan golongan;

p. Musyawarah dilakukan dengan akal sehat dan sesuai dengan hati nurani yang luhur;

q. Keputusan yang diambil harus dapat dipertanggungjawabkan secara moral kepada Tuhan Yang Maha Esa, menjunjung tinggi harkat dan martabat manusia, nilai-nilai kebenaran dan keadilan yang mengutamakan persatuan dan kesatuan demi kepentingan bersama;

r. Memberikan kepercayaan kepada wakil-wakil yang dipercayai untuk melaksanakan pemusyawaratan (Yusdiyanto, 2016).

Sila ke-4 Pancsila merupakan cerminan nilai kearifan lokal masyarakat Indonesia. Kearifan lokal yang digali, dipoles, dikemas, dipelihara dan dilaksanakan dengan baik bisa berfungsi sebagai alternatif pedoman hidup manusia (Budiyono \& Feriandi, 2017). Pancasila merupakan rangkaian kesatuan dan kebulatan yang tidak terpisahkan (Sunarjo, 2014). Oleh karena itu, musyawarah mufakat merupakan pencerminan kearifan lokal yang harus dipegang dalam kehidupan berbangsa dan bernegara dewasa ini.

\section{Pemilihan Umum Dalam Prespektif Pancasila Sila Ke -4}

Pemilihan umum yang diselengarakan secara periodik lima tahun sekali hakekatnya merupakan suatu pesta kedaulatan rakyat yang merupakan sarana mewujudkan sistem demokrasi. Artinya bahwa pemilu melindungi serta menjamin hak setiap individu untuk memilih maupun dipilih, sebagai pemimpin serta perwakilan di lembagalembaga negara yang merupakan representasi dari kedaulatan yang dijamin oleh negara sebagai entitas komunal yang secara formal diakui keberadaanya.

Sebagai jaminan terselengaranya kedaulatan rakyat yang merupakan prinsip dari demokrasi dimana pemerintahan negara dari rakyat, oleh rakyat dan untuk rakyat tentunya tidaklah sama dari setiap negara satu dengan negara yang lainya. Demokrasi di negara seperti Negara Amerika Serikat tentunya berbeda dengan demokrasi yang ada dinegara Indonesia hal ini sebagaimana dinyatakan oleh Soepomo bahwa sungguh benar, dasar dan bentuk susunan dari suatu negara itu 


\section{Pemilihan Umum dalam Sistem Demokrasi Prespektif Sila Ke- 4 Pancasila}

Yusuf Eko Nahuddin

berhubungan erat dengan riwayat hukum dan lembaga sosial dari negara itu, berhubung dengan itu maka apa yang baik dan adil untuk suatu negara belum tentu baik dan adil untuk negara lain, oleh karena itu keadaan tidaklah sama (Manan, 2012). Oleh karena itu, maka pemilihan umum sebagai sarana demokrasi yang bukan demokrasi barat, dan juga bukan demokrasi yang lainya, tetapi demokrasi yang berlandaskan serta berasaskan sila-sila Pancasila.

Prinsip dan asas ini menjadi pembeda dari pemilihan umum sebagai sarana demokrasi di negara yang tidak berasaskan Pancasila. Dimana bukan hanya sekedar menguasai mayoritas saja yang hanya melihat kuantitas semata melainkan juga mengedepankan kualitas figur dari para putraputri terbaik bangsa ini yang mempunyai jiwa dan pemikiran yang bijaksana yang mengedepankan kehikmatan untuk kebaikan bersama.

Terselengaranya pemilihan umum yang kualitas dibutuhkan peran partai politik untuk menjadi kawah candra dimukanya para kader untuk dapat di didik, di gembleng menjadi individuindividu yang mempunyai kredibelitas, integritas serta akseptabilitas dan juga popolaritas karena prestasi, dedikasi serta loyalitas kepada bangsa dan negara (Nahuddin, 2013). Sehingga terwujud serta tercapai tujuan diselengarakanya pesta kedaulatan rakyat yakni terpilihnya insan-insan yang benarbenar pilihan karena kepantasan untuk dipilih secara kapasitas manusianya lebih baik dari pada yang lainya yang tidak terpilih.

Hal inilah yang merupakan wujud pemilihan umum yang mengedepankan nilai-nilai luhur Pancasila sila ke empat yang menunjukan bahwa rakyat yang berdaulat itu dipimpin oleh benarbenar orang yang hikmat dan bijaksana serta mempunyai mengedepankan permusyawaratan didalam pengambilan setiap keputusan yang dilandaskan atas kemanfaatan atau kemaslahatan bagi seluruh bangsa Indonesia tanpa terkecuali melihat suku, ras, agama maupun golongan semata. Pemi- lihan umum yang seperti inilah yang merupakan wujud dari Pancasila sila ke -4 itu yang merupakan bentuk demokrasi yang berasaskan nilai-nilai Pancasila.

Pemilahan umum bersistem demokrasi berasaskan Pancasila bukan merupakan kelatahan semata yang hanya mengikuti tren demokrasi negara lain. Sehingga hanya terkesan formalitas semata dimana pemilihan umum hanya sekedar diadakan supaya terlihat demokratis semata yang tampak hanya persaingan dan semangat untuk melakukan segala cara demi sebuah kemenangan.

Prakteknya pemilihan umum sebagaimana dalam latar belakang di atas banyak kejadiankejadian atau persoalan-persoalan yang justru jauh bahkan menciderai nilai-nilai kerakyatan, nilai-nilai kehikmatan dan kebijaksanaan, bahkan hakekat musyawarah yang berlandaskan kekeluargaan pun tampak hilang dari adanya tindakan ilegal didalam proses pemilihan umum seperti mony politik, kampanye hitam, mengunakan isu ras, agama dan golongan bahkan segala cara ditempuh untuk mendulang suara mayoritas demi kemenangan. Bukan mengedepankan pendekatan ide gagasan maupun solusi sebagai tawaran program untuk nantinya akan dilaksanakan bila terpilih atau mendapat dukungan mayoritas.

Cara-cara yang negatif pada kenyataanya akan berdampak kepada kualitas dari pemenang dan juga akan berdampak bagi kinerja pemimpin serta wakil-wakil rakyat yang terpilih tersebut. Prespektif Pancasila sila ke-4 adalah mengedepankan terpilihnya insan-insan yang berkualitas secara pribadi yang mencerminkan jiwa yang bijaksana dalam konsep agama adalah manusia yang ulul albab yakni manusia yang sempurna yang mampu, mau serta tahu cara untuk memanusiakan manusia.

Ketidak berhasilan pemilihan umum yang mampu untuk terpilihnya insan-insan yang ulul albab secara umum dan berkapasitas, kredibelitas, integritas serta akseptabilitas dan juga popolaritas karena prestasi, dedikasi serta loyalitasnya kepada 
negara maka pemilihan umum yang demikian adalah pemilihan umum yang bukan pemilihan umum yang berlandaskan Pancasila yang mencerminkan sila ke -4 Pancasila yang merupakan harga diri bangsa ini sehingga demokrasi yang terbangun bukanlah bentuk demokrasi yang berasaskan Pancasila melainkan demokrasi yang berlandaskan kebebasan, hak asasi manusia yang mengarah kepada demokrasi barat yang tidak mencerminkan asas kekeluargaan dan kegotongroyong yang merupakan jati diri kearifan lokal bangsa Indonesia.

Karena hampir dipastikan bila hasil pemilihan umum yang terpilih adalah insan-insan yang tidak baik dalam arti hanya karena kekuatan modal dan popolaritas semata maka hampir pula dipastikan pemimpin dan wakil-wakil rakyat yang terpilih tidak mencerminkan insan yang menjiwai nilai nilai kerakyatan yang bijaksana penuh dengan kehitmatan dan mengedepankan musyawarah didalam pengambilan keputusan serta mengupayakan dialogis kontruktif dalam pengambilan keputusan serta didasarkan kemaslahatan dalam setiap gagasan yang diputuskan.

Pemilihan umum adalah sarana untuk mewujudkan demokrasi yang ideal sesuai dengan prinsip dan asas demokrasi Pancasila yang menjiwai nilainilai kebijaksanaan dan kehikmatan dalam mengambil keputusan untuk menyelesaikan persoalan yang semata-mata bukan hanya didasarkan kepada suara mayoritas saja. Melainkan juga suara bulat yang diputuskan dengan penuh perenungan oleh wakil-wakil rakyat yang merupakan insan sempurna yang merupakan manusia pilihan diantara jutaan manusia yang lainnya.

\section{Kesimpulan}

Pemilihan umum adalah sarana demokrasi yang saat ini paling efektif untuk mengikut sertakan jutaan rakyat untuk menyalurkan pendapatnya atau aspirasinya dalam menentukan pemimpin maupun perwakilanya yang duduk di lembaga eksekutif maupun legislatif. Pemilu harus diselengarakan sebagai perwujutan dari pemaknaan sila ke -4 Pancasila yang tercermin dari nuansa pemilihan umum dengan mengedepankan pendekatan dialogis visi dan misi sebagai solusi persoalan bangsa yang dilakukan oleh peserta pemilihan umum yang benarbenar mencerminkan insan-insan yang berjiwa bijaksana, penuh kehikmatan dalam mengambil keputusan dan menjunjung tinggi rasa kekeluargaan dan kegotongroyongan yang tampak kepada insan-insan pilihan yang memenuhi kriteria keterpilihan yakni kredibelitas, integritas serta akseptabilitas dan juga popolaritas karena prestasi, dedikasi serta loyalitas kepada bangsa dan negara. Implementasi Sila Ke -4 Pancasila dalam pemilihan umum yang mengedepankan kekuatan modal, pencitraan serta tindakan-tindakan menyimpang sudah saatnya untuk ditanggalkan. Demokrasi Pancasila bukanlah pemilihan umum yang mengedepankan persaiangan dan pemaksaan dengan keuatan modal dan kekuatan lainnya.

\section{DAFTAR PUSTAKA}

Arifin, Syahriani, Makna Sila Ke -4 Pancasila, http:// syahri93.blogspot.co.id, 07/2013.

Budiyono, B. and Feriandi, Y.A., 2017. Menggali Nilai Nilai Kearifan Lokal Budaya Jawa Sebagai Sumber Pendidikan Karakter. In Prosiding Seminar Nasional Bimbingan dan Konseling (Vol. 1, No. 1, pp. 92-103).

Ervianto, Toni. Potensi Permasalahan Dalam Penyelengaaan Pemilu, detikNews, Rabu 25 Januari 2017.

Huda, Ni'matul. 2014. Ilmu Negara, Cet. 6. Rajawali Pers. Jakarta.

Manan Bagir. 2012. Membedah Undang-Undang Dasar 1945, Cet.. 1. UB Pers. Malang.

Muslimin, H. 2016. Tantangan Terhadap Pancasila Sebagai Ideologi dan Dasar Negara Pasca Reformasi. Jurnal Cakrawala Hukum, 7(1), 30-38. doi:10.26905/ idjch.v7i1.1791.

Nahuddin, Eko Yusuf. 2013. Pengkaderan Partai Politik Kepada Anggotanya Dalam Rangka Penentuan Calon 


\section{Pemilihan Umum dalam Sistem Demokrasi Prespektif Sila Ke- 4 Pancasila}

Yusuf Eko Nahuddin

Legisltif. Skripsi, Fakultas Hukum Univeritas Merdeka Malang. Malang.

Ranadireksa, Hendarmi. 2007. Visi Bernegara Arsitektur Konstitusi Demokratik, Cet. 1. Fokusmedia. Bandung.

Sunarjo, S. 2017. Peradilan Sebagai Pilar Negara Hukum Dalam Perspektif Pancasila. Jurnal Cakrawala Hukum, 19(1), 71-81. doi:10.26905/ idjch.v19i1.1132

Undang-Undang Dasar Republik Indonesia tahun 1945.

Undang-Undang Republik Indonesia Nomor 7 Tahun 2017 Tentang Pemilihan Umum.
Yusdiyanto. 2016. Makna Filosofis Nilai-nilai Sila Ke Empat Pancasila Dalam Sistem Demokrasi Di Indonesia. Jurnal of Law. Volume 10 Issue 2, AprilJuni 2016.

\section{How to cite :}

Nahuddin, Yusuf Eko. 2017. Pemilihan Umum Dalam Sistem Demokrasi Prespektif Sila Ke- 4 Pancasila. Jurnal Cakrawalah Hukum, 8(2). 
